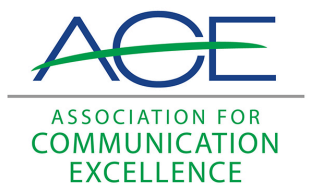

Journal of Applied Communications

\title{
Teaching Convergence in 21st Century Undergraduate Agricultural Communication: A Pilot Study of Backpack Multimedia Kits in a Blended, Project-Based Learning Course
}

Jamie Loizzo

Abigail Borron

Amanda Gee

See next page for additional authors

Follow this and additional works at: https://newprairiepress.org/jac (c) (i) (2)

This work is licensed under a Creative Commons Attribution-Noncommercial-Share Alike 3.0 License.

\section{Recommended Citation}

Loizzo, Jamie; Borron, Abigail; Gee, Amanda; and Ertmer, Peggy A. (2016) "Teaching Convergence in 21st Century Undergraduate Agricultural Communication: A Pilot Study of Backpack Multimedia Kits in a Blended, Project-Based Learning Course," Journal of Applied Communications: Vol. 100: Iss. 2. https://doi.org/10.4148/1051-0834.1033

This Research is brought to you for free and open access by New Prairie Press. It has been accepted for inclusion in Journal of Applied Communications by an authorized administrator of New Prairie Press. For more information, please contact cads@k-state.edu. 


\title{
Teaching Convergence in 21st Century Undergraduate Agricultural Communication: A Pilot Study of Backpack Multimedia Kits in a Blended, Project- Based Learning Course
}

\author{
Abstract \\ Twenty-first century agricultural communication students are expected to have an increasingly diverse set \\ of skills when they graduate.Expertise is expected in: writing, editing, design, marketing, media relations, \\ event planning, interpersonal communication, digital development, e-publications, online video, mobile \\ applications, podcasting, and social media. This expansion of needed skills is due in no small part to the \\ proliferation of communication channels and convergence of media platforms today. In order to continue \\ preparing students for professions in agricultural communication, it is imperative that the curricula reflect \\ current industry needs and available technology. In this article, one approach for expanding curricula to \\ incorporate these newer technologies by implementing backpack multimedia journalism kits for science \\ communication is discussed. The kits were developed to address these criteria: 1 ) students needed \\ opportunities to gain a variety of broad technological skills, 2) the technology had to be mobile and cost \\ effective, and 3) the technology needed to be able to produce a variety of content across a variety of \\ platforms. The mobile multimedia kits included iPad-minis and video accessories. Through an agricultural \\ communication blended-learning, project-based undergraduate course, the authors tested the \\ effectiveness of the kits, as well as researched students' perceptions and experiences with the course \\ design and mobile communication technologies. The results of the study showed students valued the \\ selected technology and gained targeted video production skills. Although students' liked the course \\ design, they experienced challenges with course requirements, time management, and using the \\ technological audio recording components.

\section{Keywords} \\ Agriculture Communication, Backpack Journalism, Convergence, iPad, Multimedia, Project Based \\ Learning, Undergraduate

\section{Authors} \\ Jamie Loizzo, Abigail Borron, Amanda Gee, and Peggy A. Ertmer
}




\section{Teaching Convergence in 2 I st Century Undergraduate Agricultural Communication:A Pilot Study of Backpack Multimedia Kits in a Blended, Project-Based Learning Course}

Jamie Loizzo, Abigail Borron, Amanda Gee and Peggy A. Ertmer

\section{Abstract}

Twenty-first century agricultural communication students are expected to have an increasingly diverse set of skills when they graduate. Expertise is expected in: writing, editing, design, marketing, media relations, event planning, interpersonal communication, digital development, e-publications, online video, mobile applications, podcasting, and social media. This expansion of needed skills is due in no small part to the proliferation of communication channels and convergence of media platforms today. In order to continue preparing students for professions in agricultural communication, it is imperative that the curricula reflect current industry needs and available technology. In this article, one approach for expanding curricula to incorporate these newer technologies by implementing backpack multimedia journalism kits for science communication is discussed. The kits were developed to address these criteria: 1) students needed opportunities to gain a variety of broad technological skills, 2) the technology bad to be mobile and cost effective, and 3) the technology needed to be able to produce a variety of content across a variety of platforms. The mobile multimedia kits included iPad-minis and video accessories. Through an agricultural communication blended-learning, project-based undergraduate course, the authors tested the effectiveness of the kits, as well as researched students' perceptions and experiences with the course design and mobile communication technologies. The results of the study showed students valued the selected technology and gained targeted video production skills. Although students' liked the course design, they experienced challenges with course requirements, time management, and using the technological audio recording components.

\section{Key Words}

Agriculture Communication, Backpack Journalism, Convergence, iPad, Multimedia, Project Based Learning, Undergraduate

\section{Literature Review}

Picture this: A well-known agriculture company has posted a position for a 'Communications Specialist.'The job description is posted online and circulated to agricultural communication undergraduate programs across the country. The position is described as following:

The Communications Specialist should be a motivated individual with a passion for agriculture and should work well alone or in teams. The job duties include writing, public speaking, media relations, crisis communication, branding and marketing, event planning, web design, video production, e-publication development and design, as well 
as producing podcasts and maintaining messaging efforts through social media channels. The Communications Specialist should have background knowledge of agriculture science concepts and current issues facing the industry nationally and internationally. A bachelor's of science in agricultural communication is required, along with examples of the candidate's writing and multimedia work.

While the presented description is hypothetical, it is rooted in what is becoming the reality of a $21^{\text {st }}$ century agricultural communication career. In the education literature, $21^{\text {st }}$ century skills are defined as the competencies students need in order to be successful in a fast-paced, technologically rich, global society (Tucker, 2012). The Partnership for $21^{\text {st }}$ Century Learning (2015) outlined the 'Four C's' of 'Learning and Innovation Skills' to include: (1) critical thinking, (2) communication, (3) collaboration, and (4) creativity. These competencies relate to the context of our growing global society, technology, and connectivity. While discussions of $21^{\text {st }}$ century skills are often focused on PK-12 education, the framework can also be applied in undergraduate education programs, including agricultural communication. Within the discipline, it is important to determine and identify proficiencies agricultural communication students need to master on their paths to becoming agricultural communication professionals in what is often called 'The Information Age' (Castells, 2010). Thanks to the Internet and emerging mobile multimedia technologies, communication today is fast paced, in real time, and at consumers' fingertips.

Specifically in the communication literature, Morgan (2010) recommended that curricula be updated every two to five years to stay relevant and that, in order to adequately prepare students for the workforce, communication programs need to incorporate convergence as it relates to specialized knowledge areas and media platforms (Lowrey, Daniels, \& Becker, 2005) Taking an instructional design (ID) approach to developing an agricultural communication curriculum, the first step is to complete a needs assessment (Molenda, 2013). This comprises asking questions such as: What do the various agricultural communication stakeholders believe to be the core competencies of the discipline and profession? What should be included in a curriculum to foster the development of $21^{\text {st }}$ century agricultural communication skills? Required competencies can be identified by examining current job descriptions and internships, as well as considering the positions of various stakeholders such as the agriculture industry, academic leaders, and students. From these viewpoints, relevant $21^{\text {st }}$ century agricultural communication skills can be identified.

To assist in compiling needs assessment data, recent studies can be drawn upon that have examined industry, faculty, and student perceptions of agricultural communication curricula and skills needed in today's profession. In a Delphi study of industry participants $(n=37)$, Morgan (2013) reported that within the 'Core Area of Communication' 91.7\% agreed with the statement that agricultural communicators should be able to "effectively communicate verbally" and $87.5 \%$ agreed agricultural communicators should understand "the media mix and how to use them [media] effectively and efficiently" (p. 23). In an additional Delphi study of academic stakeholders, faculty $(n=19)$ from 14 different universities agreed professional skills such as writing, speaking, and critical thinking are foundational competencies for agricultural communication students to master. Faculty also acknowledged the growing need for technology-based skills such as those involved in podcasting, web design, and video production (84.4\%) (Morgan \& Rucker, 2013, p. 56).

On the student side, Watson and Robertson (2011) surveyed agricultural communications freshmen at Oklahoma State University, Texas Tech University, and Texas A\&M University $(n=$ $100)$ and found half of them "expected to take an equal amount of agricultural and communication 
courses" and 70.6\% "expected to learn a broad set of communication skills such as public relations, writing, and web design." Students also "expected to enroll in a least one communications-based writing course" (94\%) and "to complete at least one agricultural communications internship" (92.6\%) (p. 10-11).

As indicated in the outlined studies, it appears many of the traditional and foundational agricultural communication competencies, expectations, and professional skills remain the same: writing, editing, public speaking, design, marketing, media relations, event planning, interpersonal communication, and ethics. Concurrently, references to skills tied to $21^{\text {st }}$ century competencies are becoming more frequent in the literature and professional job descriptions. Agricultural communicators are expected to have experience with: digital development, web design, e-publications, virtual events, online video, mobile applications, podcasting, and social media (Boers, Ercan, Rinsdorf, \& Vaagan 2012; Tucker, 2014). Many of these $21^{\text {st }}$ century, digitallyfocused professional skills have emerged, at least in part, from the convergence of communication technologies, media platforms, professional communication roles, and audience information consumption (Kolodzy, Grant, DeMars, \& Wilkinson, 2014).

\section{Convergence of Technologies, Roles, and Information Consumption}

Media convergence is often described as "technical convergence of print media to electronic media and telecommunications” (Gundelsweiler \& Filk, 2012, p. 47). Convergence is predominantly discussed as the result of print, television, and radio media platforms coming together online (Boers, Ercan, Rinsdorf, \& Vaagan, 2012). Newspapers, magazines, television news, and radio are increasingly developing content not only for their originally intended platforms, but also for websites, YouTube, blogs, and social media sites. Boers et al. (2012) advise media producers to "consider the multi-channel perspective from the beginning" (p. 54). In agricultural communication, this is also relevant as agricultural audiences are receiving and interacting with messages through a variety of communication platforms.

The 2013 'State of Journalism' report by the Poynter Institute for Media Studies provided insight into educators' and practicing journalists' $(n=1,800)$ views on whether or not journalism education programs are "keeping up with industry changes." The report noted that 39\% of educators and $48 \%$ of newsroom leaders responded, "the academy is not keeping up with changes in the field" (Poynter, 2013, p. 2). Sarachan (2011) pointed out a need for communication programs to consider a "convergence curriculum" to prepare budding communicators for journalism and public relations jobs that require the use of mobile and interactive technologies for message delivery. Sarachan surveyed communication departments $(n=110)$ across the country and found that programs were either currently or planning to teach a variety of convergence courses with titles such as "Beginning Web Design," "Digital Storytelling for Convergent Journalism," and "Communications in the Virtual World" (p.165). The research also showed that communication educators $(68 \%)$ were teaching courses based on communication theory with practical digital convergence skills being integrated.

Another way communication practices are converging is within professional roles. For instance, going back to the hypothetical 'Communications Specialist' position described at the beginning, it is apparent that one person is expected to carry out the responsibilities of public relations, marketing, photographer, designer, programmer, and journalist. Therefore, these oncesegmented jobs and duties are converging into a small number of professional communication positions within agricultural companies, media, government agencies, and non-profits. 
Consider the following current examples of the convergence of technology platforms and professional skills in an agricultural communications context:

- Beck's Hybrids 'Why I Farm' marketing and sales campaign (http://www.whyifarm.com). Communication specialists developed websites, blogs, photos, videos, and social media sites. Journalism, public relations, and technical skills were involved in the development of this campaign. Required skills included interviewing, writing, and developing features about farmers' personal stories.

- Monsanto's 'America's Farmers' campaign (http://www.americasfarmers.com). This effort also required the communications specialists to employ a combination of communication and technology skills across a variety of platforms.

- Harvest Public Media (http://www.harvestpublicmedia.org). This site comprises a collaboration of National Public Radio (NPR) stations and reporters covering agricultural news. In addition to delivering the stories via radio airwaves, online photos, videos, and social media were used.

- National Geographic. Traditionally, National Geographic was a print publication only, but it now presents cross-platform content. Their recent focus on 'The Future of Food: How to Feed Our Growing Planet' (http://food.nationalgeographic.com) included hard copy magazine editions, as well as a website with interactive content, such as articles, videos, and social media posts.

These examples provide concrete evidence of how agricultural communication skills and careers are evolving in the $21^{\text {st }}$ century. From the outlined examples and with an eye toward developing future agricultural communicators, the following questions are posed: What technology best enables the development of $21^{\text {st }}$ century skills among undergraduate agricultural communication majors? What technology is the most cost effective? How can agricultural communication programs get the most out of the purchased technology across classes, internships, study abroad experiences, and college and extension programs?

The authors' response to these questions has been to develop, implement, and research the use of multimedia 'backpack journalism' kits intended for developing Internetbased communication projects via mobile technologies. In the following section, backpack journalism technology and the authors' approach to assembling mobile, multimedia agricultural communication kits are discussed.

\section{Mobile Agricultural Communication}

As noted earlier, current and future agricultural communicators need not only to write, but also to develop digital storytelling proficiencies, using photo slide shows, YouTube videos, websites, podcasts, and social media messages. In order to achieve these multi-platform communication goals, mobile technologies are becoming more crucial for both writing and capturing sound and images, as well as producing content and posting it to the web. A review of the literature regarding digital journalism trends showed that news media, public relations and communications companies, and the public have quickly adapted to using mobile devices, such as smartphones and tablets, for producing and distributing content on the Web (Westlund, 2013). Given this, there is no longer a need to carry large, bulky equipment into the field to take photos and record audio and video. Mobile technologies can now produce content at a high enough quality that is sufficient for online viewing. 
It is important for agricultural communication educators to notice this trend toward mobile content production and design and to implement courses preparing students for mobile communication. Keeping this in mind, a plan was developed to implement and research the use of "multimedia kits for science communication," otherwise known as backpack journalism kits, in the agricultural communication undergraduate program at a large Midwestern university.

Backpack multimedia communication refers, specifically, to mobile technology carried in a light, portable bag for in-the-field recording, writing, and web content production. As the authors considered which technologies to purchase, these criteria were kept in mind: 1) students needed opportunities to gain a variety of broad technological skills, 2) the technology had to be mobile and cost effective, and 3) the technology needed to be able to produce a variety of content for the web across a variety of contexts. After considering these criteria, the cost of purchasing and implementing effective mobile multimedia kits was investigated.

\section{Research Questions}

There is a need for agricultural communication programs to update their curricula to incorporate mobile technologies and innovative teaching designs, in order to prepare undergraduates for $21^{\text {st }}$ century careers. This study represents a first step toward integrating and researching iPad multimedia science communication kits in an agricultural communication undergraduate program. More specifically, we implemented a blended project-based learning $(\mathrm{PjBL})$ design, with mobile communication kits, in an agricultural communication course. There were multiple research questions focused on the design of the multimedia course, as well as the implementation and use of the mobile technology for science communication. The research questions were:

1. What are students' perspectives of the blended, $\mathrm{PjBL}$ format?

2. What are students' perceptions of learning about agricultural science concepts through the process of developing an online video?

3. How do students describe their experiences using iPad-minis for video production?

The following section describes the research context and data collection methods.

\section{Methods}

\section{Technology Selection and Implementation}

We reviewed digital video camera and audio gear options, but decided against investing in a specific camera with limited functionality. Instead, we ultimately arrived at implementing iPadminis, with video accessories, for agricultural communication. With the addition of a bluetooth keyboard, mobile case, wireless microphone, mini-top light, lenses, and applications, such as Filmic Pro and iMovie, the iPad-mini operates as a tablet for writing, video production, photography, and uploading content to the Internet. Through various grant funding, we purchased ten multimedia kits. Each kit cost approximately $\$ 1,400$ and included: Logitech Bluetooth keyboard, iOgrapher (http://www.iographer.com/) iPad-mini case, Polaroid lenses, Sennheiser shotgun microphone, Sony Bluetooth wireless microphone, audio mic cable for iPad, Manfrotto LED light-mini, and Ravelli lightweight aluminum tripod. Figures 1 and 2 show the multimedia technology selected for the backpack kits. 


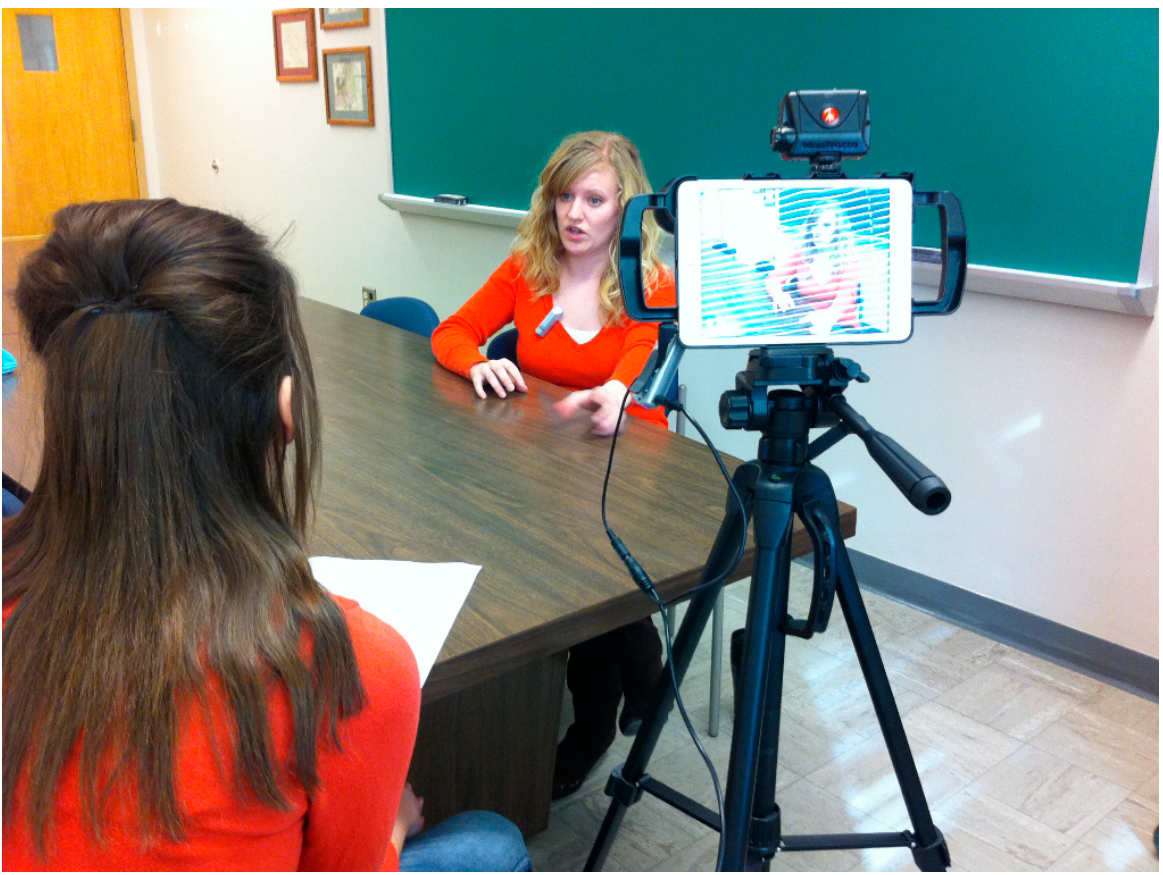

Figure 1. An agricultural communication undergraduate student uses an iPad-mini and video accessories to record a video interview.

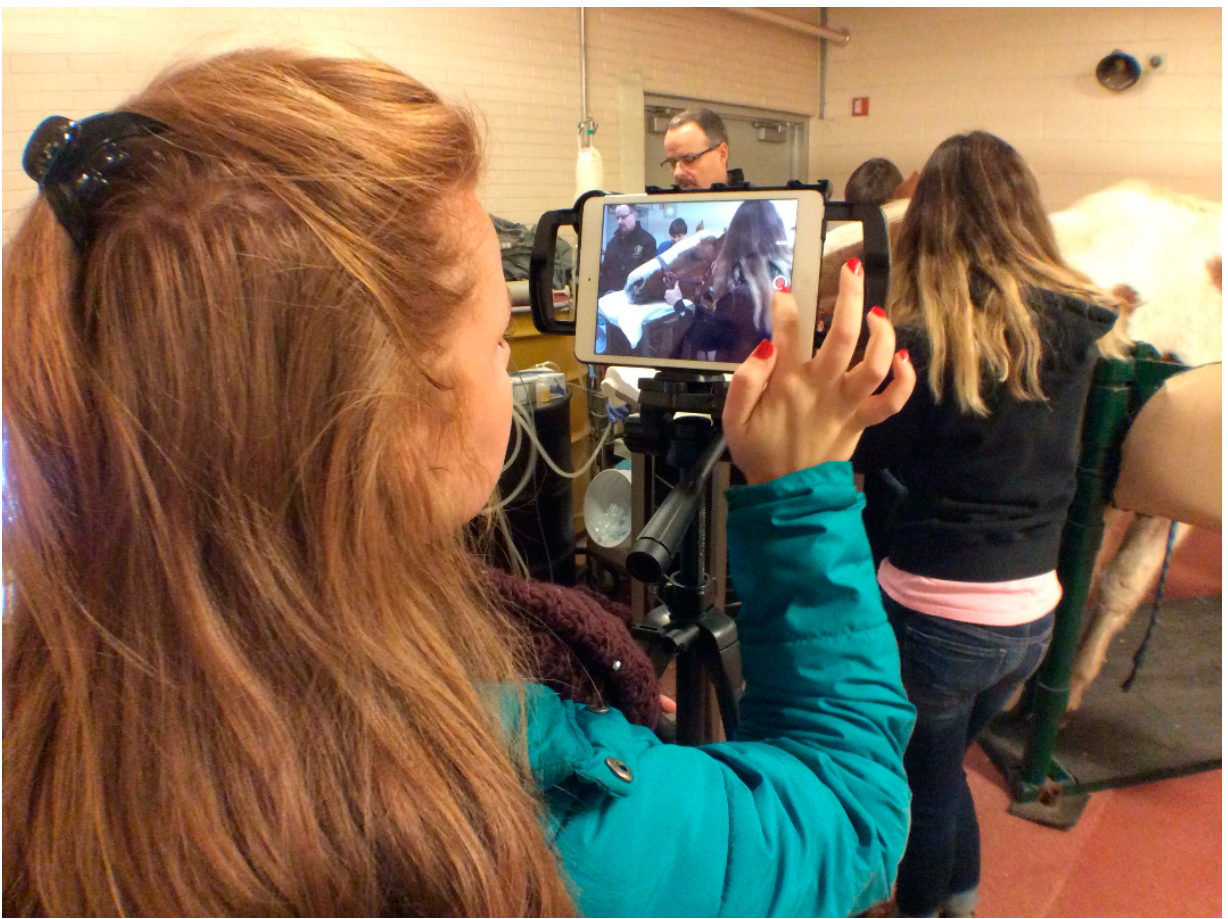

Figure 2. An agricultural communication undergraduate student uses an iPad-mini and video accessories to record footage of veterinary scientists conducting a horse respiratory test.

We believed the iPad-minis, coupled with the video gear, had the potential to serve a variety of communication purposes from writing and multimedia content creation to online and social media connectivity. 


\section{Research Context}

We developed, facilitated, and piloted a course during the spring semesters of 2013 and 2014, titled "Multimedia in Agricultural Communication" based on a blended, PjBL design. In the first iteration of the course, students produced videos for an Extension small farms team using traditional video cameras and edited their footage in a cloud-based online program called WeVideo (Loizzo \& Lillard, 2015). Based on the first pilot of the course, and the need to integrate mobile efficiency, we quickly realized the need to implement the multimedia backpack kits for the 2014 iteration.

The blended learning instructional design approach for the 2014 course was similar to what is popularly called the "flipped classroom" model (Kim, Kim, Khera \& Getman, 2014). That is, our course met face-to-face once a week for hands-on work such as learning how to use the multimedia technology and editing final project videos, while the course instruction, readings, and discussion were conducted online via a learning management system (LMS). The majority of students' time was spent online and in the field developing the final projects.

$\mathrm{PjBL}$ involves complex projects "based on challenging questions or problems that involve students in design, problem-solving, decision making, or investigative activities" (Thomas, 2000, p. 1). According to the Buck Institute for Education (2015) the $\mathrm{PjBL}$ course design involves the following: 1) in-depth inquiry, 2) a driving question, 3) a focus on what students need to know, 4) student voice and choice, 5) revising and reflection, and 6) a public viewing of the final project. Table 1 demonstrates how the multimedia agricultural communication course addressed the key components of the $\mathrm{PjBL}$ framework: 
Table 1

\begin{tabular}{ll} 
Project-based Learning Design of "Multimedia in Agricultural Communication" Course \\
\hline PjBL Framework & Agricultural Communication Multimedia Course \\
\hline In-depth inquiry & Agricultural science topic \\
& Mobile device usage \\
& Video production \\
Driving question & How can we, as multimedia communicators, use mobile \\
& technologies to develop science communication videos for \\
& our college's Office of Agricultural Research? \\
Need to know & Digital storytelling \\
& Interview technique \\
& Video treatment \\
& Video terms \\
& Video shooting and editing \\
& Video parameters: 1 scientist, 1 grad student, visual topic \\
Student voice and choice & Select and research topic \\
& Class time usage \\
& Discussions \\
Revision and reflection & Journals \\
Public audience & Peer Review \\
& Senior Associate Dean \\
& Scientists \\
Instructors & Peers \\
& Online viewers \\
&
\end{tabular}

Students in the 2014 course were required to develop a video project featuring an agricultural science topic of their choice for the Research Programs Office of the College of Agriculture and for the college's YouTube channel. The students not only had to learn how to use the multimedia kits, but also the basics of digital storytelling and mobile technology, as well as research their video topic. Table 2 highlights the learning objectives and formative and summative evaluation plans for the course. 
Table 2

Learning Objectives, Formative Assessment, and Summative Assessment Design for "Multimedia in Agricultural Communication" Course.

\begin{tabular}{lll}
\hline Objective & Formative Assessment & Summative Assessment \\
\hline $\begin{array}{l}\text { 1) Describe and apply digital } \\
\text { storytelling and interviewing } \\
\text { techniques }\end{array}$ & $\begin{array}{l}\text { Topical and target audience } \\
\text { analysis }\end{array}$ & $\begin{array}{l}\text { End of semester presentation } \\
\text { to the College of Agriculture }\end{array}$ \\
& $\begin{array}{l}\text { Video planning document } \\
\text { and timeline }\end{array}$ & \\
& Online discussions and \\
& reflective journals &
\end{tabular}

2) Develop a video outline and script

3) Conduct an on-camera interview
Video planning document and timeline

Interview question

development

Shoot on-camera interviews

Shoot footage to be used with interviews

4) Edit and upload an online Reflective journals video
Peer-review of one another's 'rough cut' videos based on same rubric instructor used for final grading

Search Engine Optimization blog
Final assignment feedback and grade by instructor

Final video project

Peer review

Instructor review

Final presentation

Final video project

Rubric for assessment Instructor review and final grade

Presentation to the College of Agriculture
5) Develop a social media Social media communication plan to share the final project plan assignment

Online class discussion Reflective journals
Instructor feedback and final grade of social media communication plan assignment

\section{Research Participants}

Ten students enrolled in the "Multimedia in Agricultural Communication" course in the pilot semester (spring 2014). Seven (5 females and 2 males) of the 10 consented to participate in this research study. Pseudonyms were used to protect the students' identities. 
Table 3

\begin{tabular}{lll} 
Research Participants & \\
\hline Pseudonym & School classification & Selected research video topic \\
\hline Annie & Junior & Invasive Asian carp \\
Justin & Senior & Agriculture education \\
Morgan & Junior & Foodborne illness \\
Rachel & Sophomore & Rabbit tracking \\
Rianne & Sophomore & Swine nutrition \\
Taylor & Freshman & Agribusiness \\
William & Graduate/Master's & Orange corn \\
\hline
\end{tabular}

One of the students, William, was a graduate student from Malawi, Africa visiting as part of an international exchange program through USAID. Prior to this course William had never used an iPad-mini.

\section{Qualitative Research Methods}

Case-based qualitative methods were used to answer our research questions (Yin, 2013). A case is an event, time, place, or phenomena in which multiple perspectives are researched through multiple methods (Thomas, 2011). In the context of this study, the case was the multimedia course, including the phenomena of the course design and technology implementation, as experienced by the students. Yin (2015) recommended collecting multiple sources of data in a case study, so as to triangulate the data and build a trail of evidence for validity measures. Therefore, multiple data sources were collected, including: participant online reflection journals, assignments, final videos, and in-depth semi-structured one-on-one interviews with participants. Student online reflection journals were incorporated into the course throughout the semester. Each week, students answered writing prompts in their online journals to reflect on their progress and use of the new technology.

In an effort to mitigate researcher biases, an agricultural communication graduate student who did not design, teach, or participate in the course was trained to use the interview protocol. She then interviewed the research participants, after final grades were given. The interview questions focused on student perceptions of: 1) project development and learning about the video topic, 2) the course design, 3) and the iPad multimedia kits. The interviews were 30-45 minutes in length, video recorded, and transcribed. The researchers then coded and triangulated the interview transcripts, reflection journals, and course artifacts (e.g., assignments and final video projects) to identify and confirm recurring codes which led the development of categories and themes. Coding procedures, as described by Saldaña (2009) for use in a variety of qualitative studies, included opencoding, grouping open-codes into categories, re-categorizing, and establishing finalized themes. In order to ensure trustworthiness and validity of the findings, the categories were presented to the research participants and graduate student interviewer for member and reliability checking. The participants and interviewer approved the categories with no changes. Given the qualitative nature of this study, results are not intended to be generalizable. However, by providing rich description of our context and results, readers may find aspects of the study that transfer, or apply to, their own contexts. The Institutional Review Board approved the design of and implementation details for the study. 


\section{Results}

Five themes were identified from the data analysis. Specifically, excerpts from course artifacts and post-interviews are highlighted to support themes found across the data and to answer the research questions. Table 4 demonstrates how the themes address the research questions.

Table 4

Research Questions Connected to Themes

\begin{tabular}{ll}
\hline Research question & Theme \\
\hline $\begin{array}{l}\text { 1. What are students' perspectives of } \\
\text { the blended PjBL format? }\end{array}$ & $\begin{array}{l}\text { 1. Hands-on with online rigor } \\
\text { 2. Freedom vs. Responsibility } \\
\text { 3. Making connections with classmates } \\
\text { and scientists }\end{array}$ \\
$\begin{array}{l}\text { 2. Perceptions of learning agricultural } \\
\text { science through video production }\end{array}$ \\
$\begin{array}{l}\text { learning about agricultural science } \\
\text { concepts through the process of } \\
\text { developing an online video? }\end{array}$ & $\begin{array}{l}\text { 5. Experiences using iPad-minis for } \\
\text { video production }\end{array}$ \\
$\begin{array}{l}\text { How do students describe their } \\
\text { experiences using iPad-minis for } \\
\text { video production? }\end{array}$ & \\
\hline
\end{tabular}

\section{Theme I: Hands-on with Online Rigor}

Overall, the students expressed favorable views of the $\mathrm{PjBL}$ blended learning course design. Each student was asked to describe the course design in his/her own words. Most often, they would explain that face-to-face class time was used for hands-on work, while the online work consisted of reading and assignments. For instance, Rianne described a typical class as follows: "We would partner up and do small videos that portrayed the chapters we had read about those topics. And then, we would come back together and review what was difficult, what was easy, what we liked, what we didn't like about different things - and that would be the wrap up." In her journal, Rachel wrote, "I like how the course is laid back. I like how it's really hands-on. I like how we are interactive with the College of Ag." William said, "It was more practical oriented that remains in your life for a longer time than just to concentrate on theory."

The students also discussed how the online portions of the course were more rigorous, demanding, and challenging than they had expected. Rachel said "We wrote journals, blogs; we had the discussions, I think, as well. Those were kind of hard. I'm bad about remembering to keep doing it." Justin described, "I would say the online part was a little confusing, at first, because we had different things. We had a journal. We had a discussion. We had a blog. There for a while, I think some of us didn't even know about it. So, it was like, oh, we had to do that." Morgan mentioned that she found the online discussions to be too time-consuming and not as meaningful as an in-class discussion, "We read topics and we discussed them, but there's only so much discussion that you can do in an online sense, and so, it was kind of hard to get a feel for exactly what people were thinking just because it was typed in an electronic device." 


\section{Theme 2: Freedom vs. Responsibility}

Another theme that emerged related to students' perspectives of the $\mathrm{PjBL}$ course design was the tension between freedom and responsibility. Students discussed how they enjoyed the realworld context, freedom to choose their topics, and self-paced nature of the course. In contrast, they found that with the freedom came the responsibilities of managing their time to effectively contact scientists, conduct interviews, and edit their videos according to course milestones and deadlines. Justin said, "I liked it because it gave me [the] creativity to do what I wanted with my project." Morgan explained, "You kind of had to be a self-starter and self-motivated to get that done. So, I liked that. I think that taught us a lot. It's just mirroring what we have to do, you know in the professional world, and things like that." Rianne said, "I liked the freedom that we had, but in the same respect, I didn't [like it] because it was really frustrating at times when there were deadlines that were coming up and you couldn't meet them because you were relying on someone else, like the researcher."

Half of the students expressed difficulties in working with scientists for their videos, as the scientists were very busy and not always responsive to the student's video production schedule. Taylor proposed:

I don't know if we need to have a definite cut-off date or, if your scientist isn't cooperating, just move on and get a new scientist, or something. So that way, maybe, the class is more structured exactly how it says it will be in the syllabus, look into it, or what we could really do to improve it. It's something that's really hard to work with because the class is so dependent upon other people outside of the classroom.

Half of the students recommended that a 'bank of scientists' be developed for the course. Then, the scientists would have already agreed ahead of time to participate in the students' video projects, and the students could select their topics based on the available and participating scientists.

\section{Theme 3: Making Connections with Classmates and Scientists}

Student interviews and journals showed that another perceived outcome of the course design was that students were able to make valuable connections with classmates, as well as scientists. As this was the first time for many of the students to engage in the video production process, it was recommended that students work with one another to shoot the interviews for their respective videos. The students worked it out amongst themselves in and outside of class as to how to work together effectively. Annie said:

When I wanted to have an interview, I could just inform the whole group to say that on such and such a date, I would do a, b, c, d, and someone would volunteer to camera assist. That was a great thing in a course to say that students could help each other accomplish their goals.

In addition to developing relationships with classmates and supporting one another, the students expressed an excitement for establishing connections with real-world scientists working in the College of Agriculture. Rachel worked with an assistant professor of wildlife ecology and habitat management and said, "Once I met her, she was really good, and she wanted to work with me. So, I wanted to work with her." Rianne vividly described establishing a connection with the surine regreargher who she featured in her video: 
My researcher is really cool, and so, making that extra connection was awesome. You know, whether I ever need to contact him again, I don't know, but he's there, and I've got his email. I saw him on the street the other day and was like, "Oh hey, (Scientist's Name)!, and he was like, "Hey, how's it going, Rianne?" So, that was a really big building point as well.

\section{Theme 4: Perceptions of Learning Agricultural Science through Video Production}

As mentioned, each student chose his/her video topic as one way to incorporate the 'voice and choice' component of the $\mathrm{PjBL}$ framework in the course. Each student's prior knowledge, interest, and motivation appeared to play a role in the agricultural topic they pursued, and they ultimately learned more about their agricultural science topic through the development of the videos. Justin selected his video topic because, "I'm very involved with 4-H and youth development, and he [the scientist] works a lot with students. So, I thought that kind of fit with what I am interested in as a career." Taylor chose her topic because it related to her background and future interests: "Growing up on my family farm, I thought that I could apply what I learned to our family farm, as well as this summer I have an internship with Farm Credit, and so, I thought I could learn something that would help me prepare for that internship, as well."

Many of the students described learning more specific details about the topics they selected, as well as gaining a deeper understanding of the nature of science and research. This occurred through the process of students researching their video topics and interviewing scientists. Previously, some students had never been exposed to either the video message development process or the scientific research process. The following excerpt from Morgan's interview with a food scientist demonstrates how student engagement in and video production of real-world agricultural science topics expanded their views of research and deepened their understanding of their chosen topics:

I've never really been in a research lab before at [the university]. So, that was a fun experience. And then, I just learned a lot about the basics of listeria, and how it can affect the consumer, and how it is contracted, and where it's found, and what [the university] is doing to stop listeria outbreaks - which is really neat.

Another similarity across student experiences was the development of what is often called "soft skills." For communication professionals, these soft skills include time management, content organization, design, working with clients, and interviewing. Rianne said, "I had never conducted a video interview before, so that was a whole learning experience." Several of the students described being nervous about the video interviews, but they valued the opportunity to develop and gain more confidence in their skills through the project format.

\section{Theme 5: Experiences using iPad-minis for Video Production}

In general, the students enjoyed using and learning with the iPads. Multiple students mentioned that they liked how easy it was to use the devices that the technology was portable, versatile, and easy to troubleshoot, and that they could foresee using mobile technology in future agricultural communication careers. Justin said: 
A lot of people have an iPad, and it's kind of neat to see that you can make a video with something that's more user-friendly than a video camera, which is specifically made for making a video. I thought it was easy to transport, kind of take on the go with you and... what really helped is the editing with iMovie on the actual iPad. You don't have to upload it to a computer or anything. It's all right there in your hands.

In contrast, some of the students did not like editing on the mobile devices. For instance, Taylor discussed how it was difficult to make detailed edits using her fingertips. She explained, "I think that it was such a small workspace that it was hard to get at right where you needed to, where maybe if we would have been on an actual Mac with an actual screen that it might have been easier."

It also turned out that the Sony Bluetooth microphones and mini-plug connectors did not work consistently with the iPads and many of the students then recorded their audio using the built-in iPad microphone, causing the audio to be somewhat hollow sounding. Some of the students also reported glitches with the FilmicPro app, where the app would sometimes pause or freeze during recording. Therefore, most of the students switched to using the standard iPad camera application.

By the end of the semester, each student successfully produced a video project using the iPad-minis and accessories. They debuted their videos to a public audience including the senior associate dean of research and the scientists who participated in the projects. The videos (Figure 3) were posted to the college's YouTube channel for public audiences.

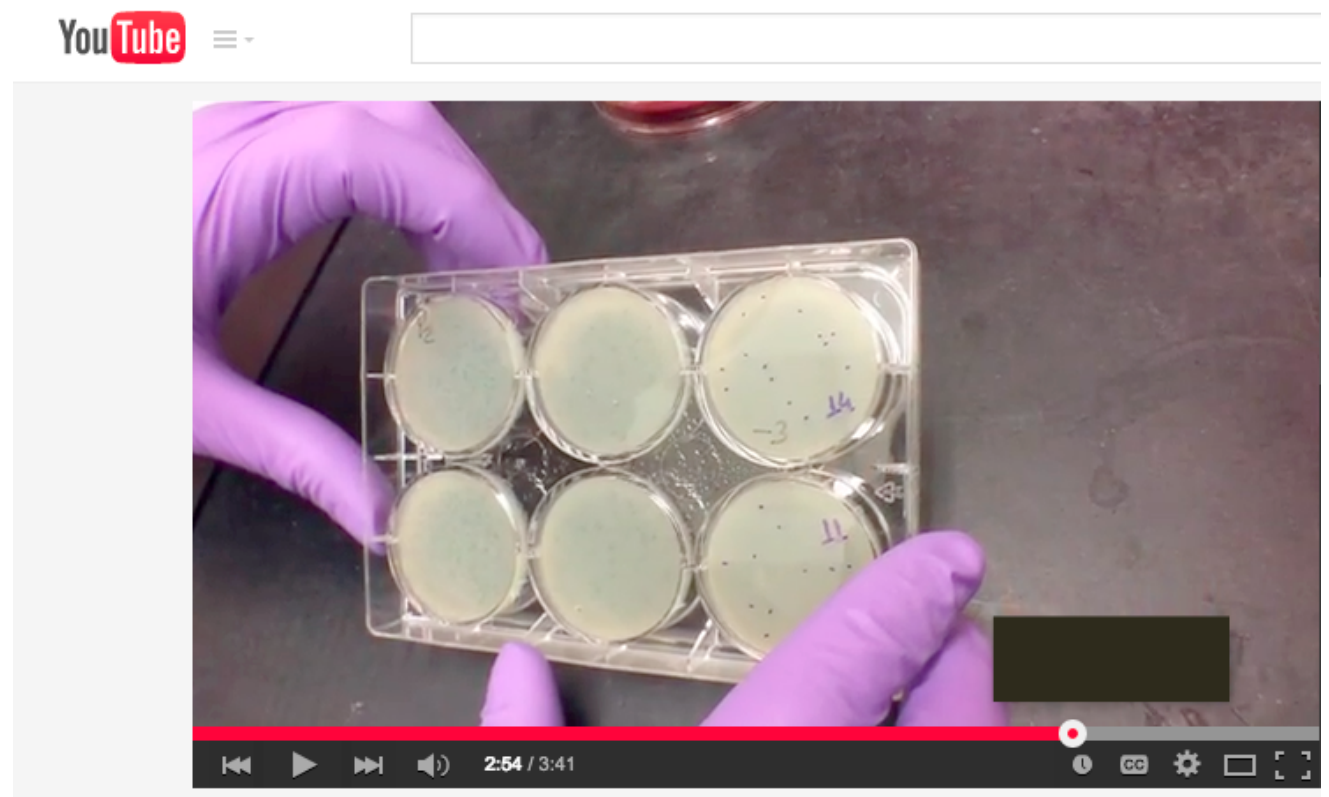

Figure 3. Screen capture of Rianne's final swine research video.

Many of the students described a sense of pride in completing their videos and acknowledged that they learned video storytelling techniques. However, they also described room for improvement in future video production efforts. Taylor said, 
I think that my final video turned out pretty well, for it being my first video. I have never done any video editing, so it was a learning process for me, and like I know some of my video wasn't the clearest and the shots could have been set up a little better, but I think the strong point of my video is the organization of it and just how things flow very logically.

The students also liked that they were a part of a program that was trying out a new, mobile, cutting-edge way to produce communications materials. Some of them described the perceived prestige that came with using the technology. Rachel described how she and a fellow student used the gear at a conference where others asked about how it works. Similarly, Rianne shot video at a college event and was excited to show the technology off to the dean. She said, "He was super intrigued and asked me all kinds of questions about how this worked and how the attachments worked, and so, it was cool to be able to not only learn how to use it myself, but also to educate others while I was still learning."

Immediately following the $\mathrm{PjBL}$ multimedia course, several of the participating students took part in a service-learning study abroad program in Romania. While overseas, the students used the multimedia kits to develop video narratives of Heifer Romania project beneficiaries (Figure 4). 


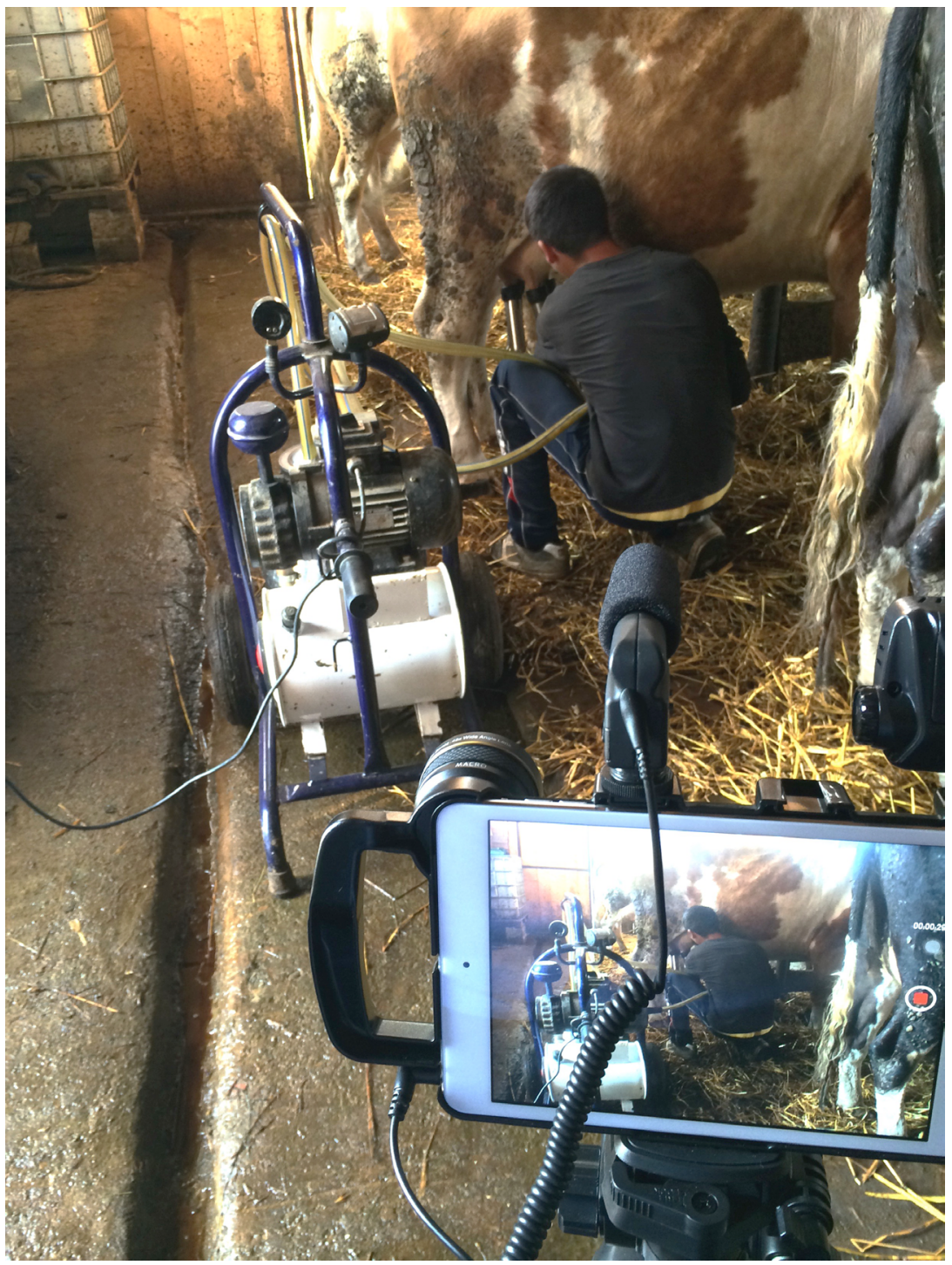

Figure 4. The iPad-mini and video accessories were used on a service-learning study abroad program to Romania, to create video narratives of Heifer Romania project beneficiaries.

\section{Limitations}

This case study examined the results of the pilot blended $\mathrm{PjBL}$ course design and $\mathrm{Pad}-$ mini technology. Although data was collected from multiple sources—such as course artifacts, student reflection journals, and post-interviews to triangulate data for sound findings-one of the major limitations of the study was the sample size $(n=7)$. Another limitation relates to the possibility of researcher bias, as one of the members of our research team was also the course developer and instructor for the course. The use of multiple researchers, however, helped mitigate this potential.

\section{Discussion and Conclusion}

Professional communication roles, approaches, and communication technologies are converging (Boers et al., 2012; Gundelswiler \& Filk, 2012). There is a need for agricultural communication undergraduate degree programs to develop new teaching methods and implement mobile technologies into curricula to effectively prepare students for $21^{\text {st }}$ century careers (Koldzy, 2014; Tucker, 2014). While the literature identifies writing, speaking, editing, and multimedia 
development as crucial skills for agricultural communicators (Morgan, 2010; Morgan \& Rucker, 2013; Watson \& Robertson, 2011), it is critical for today's programs to address convergence as it relates to media and education. Of course, training students how to strategically navigate through the ever-changing world of media technology and strategy is imperative to keep them competitive in their chosen career field. But, integration of training and application of communication theory into a blended $\mathrm{PjBL}$ environment challenges students to apply their knowledge through realworld projects based on communicating complex agricultural science topics via interactive, mobile technologies.

In this study, the blended $\mathrm{PjBL}$ course design aimed to meet these goals with students collaborating to learn digital storytelling theory via online activities and working hands-on in class to produce real-world agriculture communication videos with backpack multimedia kits. The results showed students were able to learn about agricultural science issues and research, form relationships with scientists, as well develop communication and technology skills by utilizing the multimedia kits. The students did express difficulty in tackling the real-world project and faced challenges, such as working around scientists' schedules. While the students recommended having a pre-determined bank of scientists to work with them, that would go against the $\mathrm{PjBL}$ design and instructional intent for students to function in a real-world situation (Buck, 2015). The students also found the online portions of the course to be complicated and rigorous. This could be because this particular group of students had never participated in a blended learning course before and were not familiar with online learning tools such as blogs, wikis, discussion boards, and journals.

This study has implications for agricultural communication programs and research in regard to implementing similar blended $\mathrm{PjBL}$ designs, as well as incorporating multimedia technologies into courses for teaching convergence communication. The iPad backpack kits could be incorporated into a variety of skills-based courses in agricultural communication, which include work in video production, photo essays, blogs, social media campaigns, and more. There is also the potential to use the technology for Extension and 4-H workshops where educators and students could develop multimedia communication projects within contexts of interest.

There is a substantial amount of opportunity for future research resulting from this study. The blended $\mathrm{PjBL}$ instructional design could be applied and examined across multiple agricultural communication programs at land grant institutions, as well as Extension workshops and programs. Potential research could include investigating the tension of student freedom versus responsibility in a $\mathrm{PjBL}$ design, as well as student experiences and learning within different agricultural science subjects. For instance, if the driving question focuses on climate change or genetically modified organisms, what do students learn about these controversial agricultural communication issues during the development of their project, as well as professional approaches for communicating controversial issues? On the flip side, what are scientists' perceptions of and experiences with participating in the students' projects? And, if students were to use this technology to produce content during an agricultural communication service-learning study abroad trip, how does this correlate to teaching effective cross-cultural communication strategies?

As the Poynter Institute noted (2013), the media industry perceives communication education programs to be out of touch with industry standards. During a time when communication roles and technologies are rapidly converging, it is incumbent upon agricultural communication programs to respond with convergence courses and mobile technology implementation so that students are in touch with the demands of continually evolving $21^{\text {st }}$ century 
communication careers. Utilizing a blended PjBL course design with mobile technologies has the potential to update and create a cutting edge agricultural communication program that equips students with convergence experiences and skills needed to be successful professionals. This study is a small part of the overall critical need for agricultural communication programs to advance and evolve with innovative teaching techniques and communication technologies in order to push students to develop critical thinking skills for ethically communicating controversial global issues in agriculture, food, and the environment via a variety of platforms and outlets.

\section{References}

Boers, R., Ercan, E., Rinsdorf, L., \& Vaagan, R. W. (2012). From convergence to connectivism: Teaching journalism 2.0. Online Journal of Communication and Media Technologies, 2(4), 5264.

Buck Institute for Education. (2015). What is Project Based Learning (PBL)? Retrieved from: $<$ http://bie.org/about/what_pbl>

Castells, M. (2010). The rise of the network society: The information age: Economy, society, and culture (Vol. 1). West Susses, UK: Wiley-Blackwell.

Gundelswiler, F. \& Filk, C. (2012). Future media platforms for convergence journalisms. At the Interface/Probing the Boundaries, 83, 45-57.

Kim, M., Kim, S., Khera, O., \& Getman, J. (2014). The experience of three flipped classrooms in an urban university: An exploration of design principles. Internet $\mathcal{\sigma}^{\circ}$ Higher Education, 22, 3750. doi:10.1016/j.iheduc.2014.04.003

Koldzy, J. Grant, A. E., DeMars, T. R., \& Wilkinson, J. S. (2014). The convergence years. Journalism E Mass Communication Educator, 69(2), 197-205. doi: 10.1177/1077695814521718

Loizzo, J. L. \& Lillard, P. (2015). In the field: Introducing undergraduates to Extension through a blended project-based multimedia production course. The Journal of Extension, 53(1).

Lowrey, W., Daniels, G. L., \& Becker, L. B. (2005). Predictors of convergence curricula in journalism and mass communication programs. Journalism E Mass Communication Educator, 60(1), 31-46. doi: 10.1177/107769580506000108

Molenda, M. (2003). In search of the elusive ADDIE model. Performance Improvement, 42(5), 3437. doi: $10.1002 /$ pfi.4930420508

Morgan, C.A. (2010). Competencies needed by agricultural communication graduates: An industry perspective. Journal of Applied Communications, 94(1\&2), 19-32.

Morgan, C.A. \& Rucker, K. J. (2013). Competencies needed by agricultural undergraduates: An academic perspective. Journal of Applied Communications, 97(1), 50-65.

Partnership for $21^{\text {st }}$ Century Learning (2015). Retrieved from <http://www.p21.org/>

Poynter Institute for Media Studies. (2013). State of Journalism Education 2013.1-23. Retrieved from <http://www.newsu.org/course_files/StateOfJournalismEducation2013.pdf>

Saldaña, J. (2009) The coding manual for qualitative researchers. London, UK: Sage Publications.

Sarachan, J. (2011). The path already gaken: Technological and pedagogical practices in convergence education. Journalism Eซ Mass Communication Educator, 66(2), 160-174.

Thomas, G. (2011). A typology for the case study in social science following a review of definition, discourse, and structure. Qualitative Inquiry, 17(6), 511-521. doi: $10.1177 / 1077800411409884$

Tucker, S. T. (2014). Transforming pedagogies: Integrating $21^{\text {st }}$ century skills and web 2.0 technology. Turkish Online Journal of Distance Education (TOJDE), 15(1), 166-173. doi: $10.17718 /$ tojde. 32300 
Watson, T. \& Robertson, J. T. (2011). Perceptions of agricultural communications freshmen regarding curriculum expectations and career aspirations. Journal of Applied Communications, 95(3), 6-20.

Westlund, O. (2013). Mobile news: a review and model of journalism in an age of mobile media. Digital Journalism, 1(1), 6-26. doi: 10.1080/21670811.2012.740273

Yin, Robert K. (2011). Qualitative Research from Start to Finish. New York, NY: The Guilford Press

Yin, R. K. (2014). Case study research: Design and methods. London, UK: Sage publication

\section{About the Authors}

Jamie Loizzo's professional background is in radio-television news broadcasting and agriculture communication. She has experience managing and producing electronic field trips in STEM education and videos on agricultural science topics for diverse audiences. Loizzo has research interests in informal science communication and education and instructional technology.

Abigail Borron's professional background is in disaster and risk communication within the Cooperative Extension System. As a researcher, her work focuses on culture-centered communication with emphases in marginalized audiences and university engagement.

Amanda Gee's research and professional interests center on agricultural communication, especially understanding and addressing an audience's needs in those communications. She is completing a thesis on northwest Indiana food pantry clients' and directors' perceptions of meat.

Peggy Ertmer's research interests relate to technology integration, teacher beliefs, and helping students become expert instructional designers, specifically through the use of case- and problembased learning methods. She is the Founding Editor of the Interdisciplinary Journal of Problembased Learning and teaches courses to pre-service STEM teachers, using a PBL approach. 